\title{
5 \\ Journeys in quest of cosmic power: Highland heroes in Borneo
}

\author{
Monica Janowski
}

To travel is to take a journey into yourself. — Danny Kaye

In this chapter, I will explore the nature and purpose of the journeys in which Kelabit heroes, ${ }^{1}$ talked of in legend, ${ }^{2}$ engage. I will focus in particular on the legend about a hero called Tuked Rini (Plate 5.1), a version of which I recorded in 1986, recited by Balang Pelaba ('Very Much a Tiger'), in the community of Pa' Dalih on the Kelapang River in the Kelabit Highlands of Malaysian Borneo. ${ }^{3}$ The legend of Tuked Rini is a sekono, a type of Kelabit oral literature. It tells of the adventures of a group of men, led by Tuked Rini, who explore the inner and outer reaches of the cosmos to do battle with powerful beings and bring back heads. It was told to encourage young men to carry out headhunting expeditions themselves and young women to support them in this. Tuked Rini's wife, Aruring Menepo Boong (Plate 5.2), is also an important cultural hero-her female nature balancing his male nature.

\footnotetext{
1 I define hero, as does the Oxford dictionary, as: 'A person who is admired for their courage, outstanding achievements, or noble qualities' (en.oxforddictionaries.com/definition/hero).

2 I define legend here, as does Timothy Tangherlini (1990: 385), as a 'traditional, highly ecotypified historicized narrative performed in a conversational mode, reflecting on a psychological level a symbolic representation of folk belief and collective experiences and serving as a reaffirmation of commonly held values of the group to whose tradition it belongs'.

3 I have published a book with a full version of the legend as recited by Balang Pelaba, using the legend as a means of exploring the way of life and the cosmology of the Kelabit (Janowski 2014/16).
} 


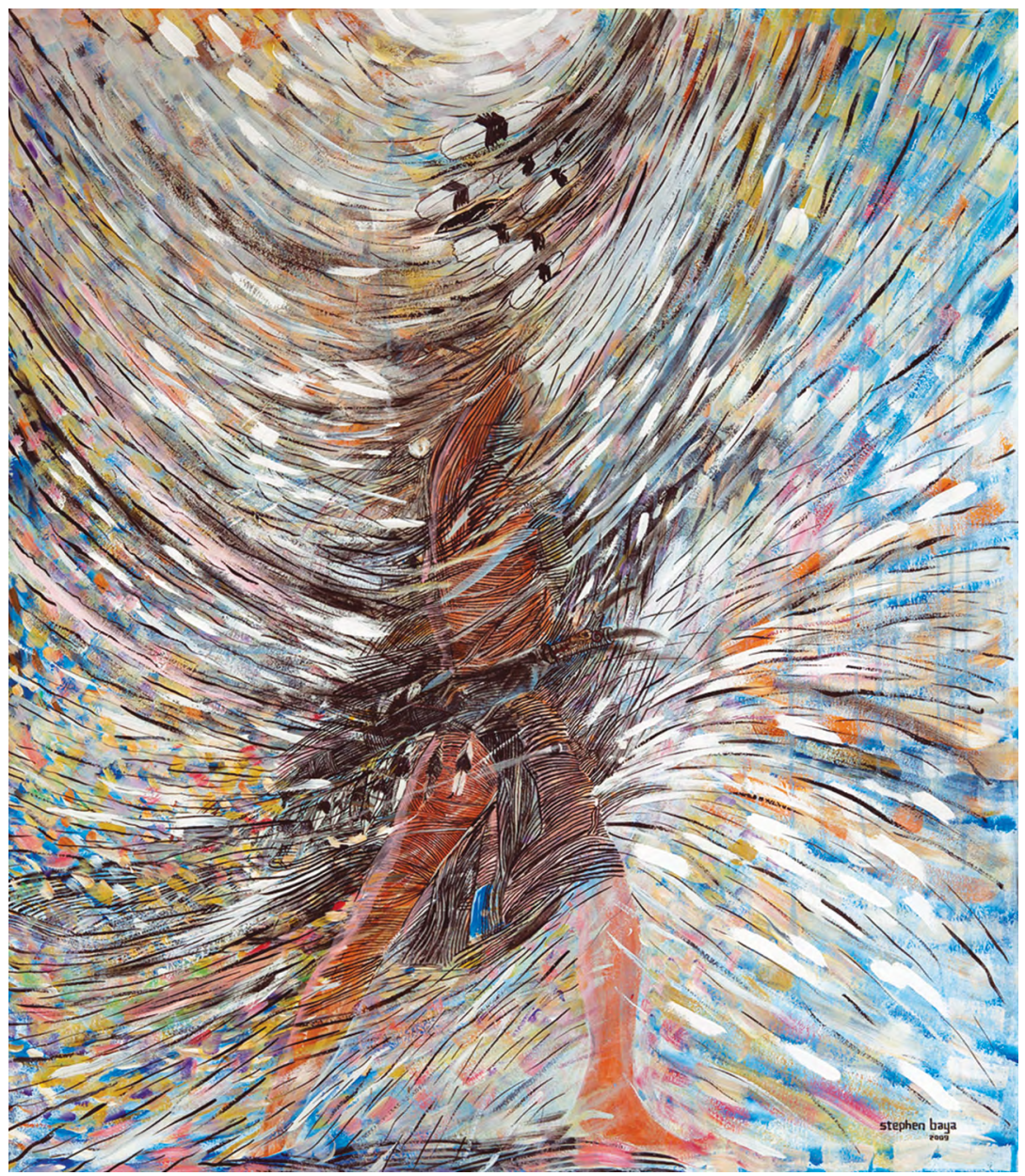

Plate 5.1 Tuked Rini Luun Atar shimmering with lalud (cosmic power) and only semi-visible

Source: Painting by Stephen Baya, 2009.

I will explore the role of lalud ('life force' or 'cosmic power') in the legend of Tuked Rini. I will suggest that the concept of lalud is key to understanding the role of these legends and their central heroes. I will focus in particular on the role of male heroes and the significance of the headhunting that lies at the core of Tuked Rini's journey through the cosmos. Finally, I will make some remarks regarding present-day journeying to gather lalud.

First, I provide an outline of the legend of Tuked Rini as related to me by Balang Pelaba on 25 November 1986. 


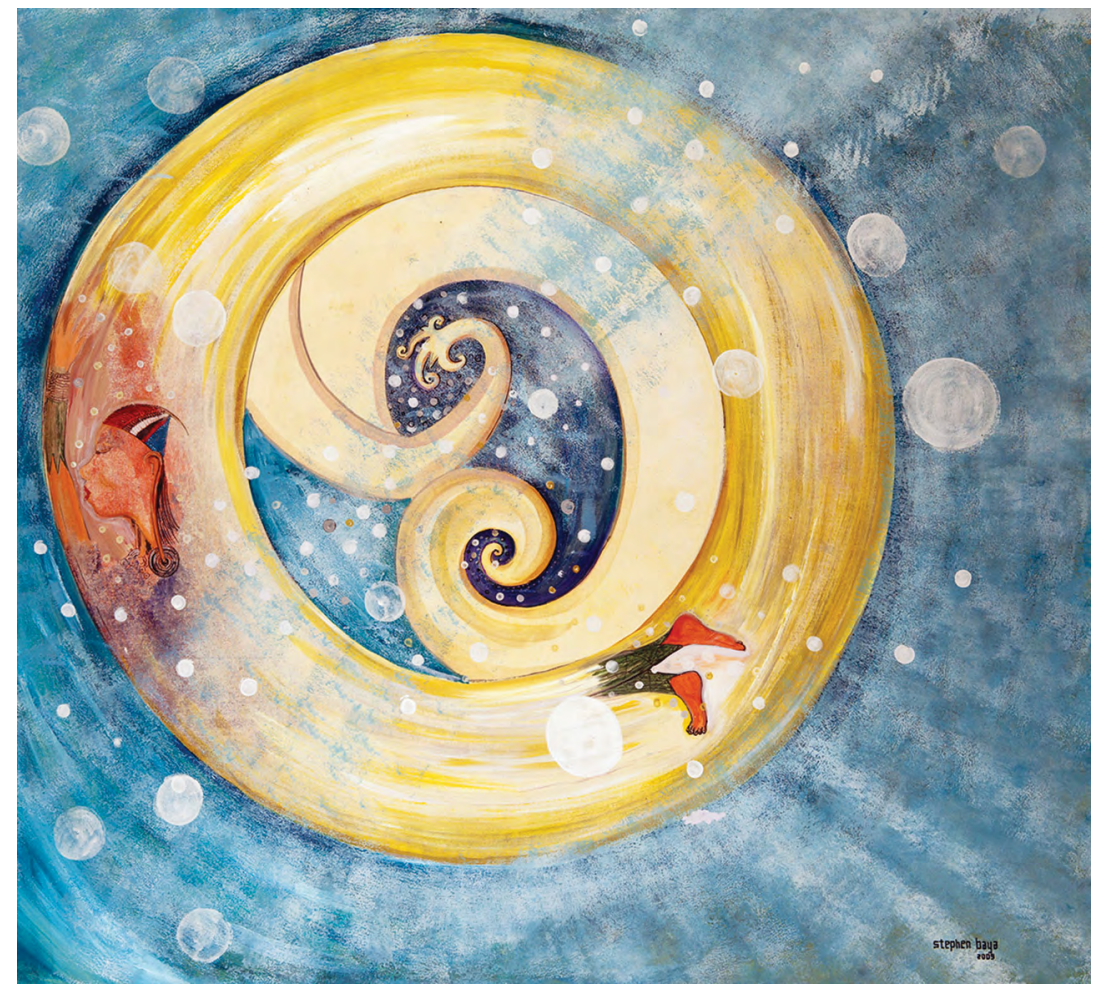

Plate 5.2 Aruring Menepo Boong, Tuked Rini's wife, carried inside his earring on the way to a feast Above the Sky (Palaii Langit)

Source: Painting by Stephen Baya, 2009.

\section{Outline of the legend of Tuked Rini}

The story begins in the early morning in the longhouse at Luun Atar ('On the Flat Land') led by Tuked Rini ('Rini Who is Support for All') and his wife, Aruring Menepo Boong ('She Who Gathers Huge [Beads]'). Aruring prepares a rice meal and invites her husband and others to eat. She recites a chant about her preparation of the rice and her carving of the door through which Tuked Rini will come.

After breakfast Tuked Rini recites a chant about his hunting ability and his desire to go hunting for a tiger. He begins to talk to his close kin about going headhunting. They decide to go to fight another powerful leader, Tuked Rini Lobang Uli' Bario Langiyung ('Rini of the Hole of the 
Moaning Wind'), and other heroes living with him inside Batu Balang Tekinang Lungung ('the Vastly Tall and Powerful Spirit Tiger Rock'). These heroes are extremely powerful, and therefore worthy enemies.

Tuked Rini and the other heroes, his close kin, get ready. Tuked Rini recites a chant describing the headhunting clothes he will put on: a tigerskin jacket and a huge and beautiful knife exchanged for beads, which is so powerful that it causes thunder to roll and blood rain to fall.

They jump off into the sky from the great stone in the river below their longhouse, with the lesser people hanging off the sword sheath of one of the heroes. His close kin accompanying Tuked Rini include Agan Bulan Makub Lungung ('Agan Who Jumps up to Knock against the Moon and the Clouds'), Agan Pun Tolang Na'an Mitun ('Agan Whose Bones Go Straight for His Target'), Lian Balang Olong ('Lian the Spirit Tiger Who Raises Many Poles at Feasts'), Tama Baru' Lanawa Balang Tolang Kayuh Ngelungung ('Father Creator Shadow-Making Spirit Tiger with Bones of Wood Who Makes a Huge Powerful Shadow'), Tagio' Balang Pekeling Kuman ('Havoc-Causing Spirit Tiger Who Exchanges Food with Others at Feasts') and Balang Katu Anak Belawan ('Descendant of Spirit Tigers, Son of Iron').

They fly for a day and a night and land at Ra'an Ayun Langit Temubong ('Pass of the Shadow of the Highest Sky'), near Ru'ib Boong ('the Huge Waterfall'). Here they make camp. Two of the heroes go to collect bamboo in which to cook their food; they are able, because of their great power (lalud), to walk on the surface of the water to reach the bamboo. They see that someone has already cut some bamboo and realise that this must have been the people living inside the Spirit Tiger Rock. When the lesser people hear about this, they are terrified and want to return home, but the heroes convince them to continue.

The people of Luun Atar now need to fight the Spirit Tiger Rock itself to get inside it to fight the people living there. The heroes battle with it for a long time and eventually one of the heroes, Agan Whose Bones Go Straight for His Target, leaps up into the sky and comes down right on top of the Spirit Tiger Rock, driving him into the ground. Tuked Rini puts his whetstone into the Spirit Tiger Rock's mouth and they go inside. 
They travel for 10 days and nights before reaching a lookout point on top of a hill, from which they can see a longhouse. It is beautiful: the roof shines like silver and there are gongs hanging at each end of the house. Obviously, there are powerful people living in the house.

That evening, Tuked Rini and Agan Whose Bones Go Straight for His Target go into the house-invisible because of their lalud. They see that everyone is drinking rice beer; the people of the longhouse have clearly just come back from a successful headhunting expedition. They see two of the heroes of the longhouse, Sewan the Spirit Tiger with Breath of Walking Fire and Siok the Spirit Tiger Who Distributes Smoke with His Fingers. Both of them are wrapped in power (lalud), which flows and flickers around them.

The next morning, Agan Whose Bones Go Straight for His Target lets out a war cry $(k i t)$, which fells many of the lesser people of the longhouse inside the Spirit Tiger Rock, and the lesser people from Luun Atar attack the longhouse and kill more of the lesser people there. Then the heroes of Luun Atar and the heroes of the longhouse inside the Spirit Tiger Rock introduce themselves formally to each other and agree to fight. They begin fighting on the ground outside the longhouse. Tuked Rini Luun Atar recites a chant about the power of his war cry, declaring that he will bring back heads for the beautiful red lady—his wife, Aruring. Thousands more of the lesser people of the Spirit Tiger Rock fall dead because of his war cry. He then joins in the fighting with the heroes of the Spirit Tiger Rock.

The heroes fight and fight. One of the heroes of the longhouse inside the Spirit Tiger Rock uses his power (lalud) to send fire sweeping across the land and kills the lesser people from Luun Atar. Only the heroes from Luun Atar are left.

At this point, the old couple up in the Highest Sky notice what is happening in the battle. One, Sinah ('Mother') Sepudau, is the ancestor of the people of Luun Atar and the other, Agan the Upright Bird, is the ancestor of the people of the longhouse inside the Spirit Tiger Rock. Sinah Sepudau, concerned for her descendants from Luun Atar, who are losing the battle, calls out to other descendants of hers, heroes living in the Kerayan River Basin who are related to the people of Luun Atar, and tells them to go to help. They drop down from the sky and set to in the battle. 
Tuked Rini of Luun Atar recites a chant about the heroes coming to help, declaring that he will take his enemy's head, to take back to his longhouse at Luun Atar. The battle continues. One of the heroes from the Spirit Tiger Rock, Siok the Spirit Tiger, catches many of the lesser Luun Atar people and drops them, killing them. Only the strongest heroes are left.

One of the Luun Atar heroes, Father Creator Spirit Tiger with Bones of Wood Who Makes a Huge Powerful Shadow, turns into a tree and falls on many of the people of the Spirit Tiger Rock.

One of the heroes from the Spirit Tiger Rock, Sewan the Spirit Tiger with Breath of Walking Fire, fights for aeons with one of the heroes from Luun Atar, Agan Whose Bones Go Straight for His Target, until Agan gets the better of Sewan and ties him up. Then they hear a woman's voice - that of The Great Spirit Mother. She declares that Sewan the Spirit Tiger and Siok the Spirit Tiger, two of the strongest heroes from the Spirit Tiger Rock, are actually from Luun Atar; they had been discarded as babies (because they were born at an inconvenient time). So Agan releases Sewan. There is a happy reunion.

Then the people of Luun Atar realise that all of the people of the Spirit Tiger Rock are dead. They have won the battle. Their own lesser people are also dead; however, one of the heroes of Luun Atar, Descendant of Tigers, uses his powerful lalud water to bring them back to life.

So, all of the people of Luun Atar return home, together with their newfound relatives, Sewan the Spirit Tiger and Siok the Spirit Tiger, and two of the heroes from the Kerayan River who had dropped down from the sky to help them. The high-born women of Luun Atar, wives of the heroes, prepare rice beer as soon as they see their husbands coming. Everyone drinks and visits with each other.

The next morning one of the heroes, Descendant of Tigers, tries to persuade Tuked Rini's wife, Aruring, to drink (and sleep) with him. She, however, refuses, reciting a chant about her high status, her desirability, her beauty and her ability to grow lots and lots of rice and to pound and husk it magically with her huge mortar-and declaring that she wants only Tuked Rini. 
The people of Luun Atar now harvest their rice fields. The people of the Luun Plain, who live across the river, are also harvesting, and the two groups of people engage in banter and play in the river, including exchanging partners for one night.

Then the people of Luun Atar hold a feast to celebrate the harvest, the new rice and the headhunting success of their heroic men. The men hunt lots of wild pigs for the feast.

\section{Highland heroes}

Tuked Rini (known as Tuked Reminii among the Lundayeh) is one of a number of heroes featuring as central figures in Kelabit and Lundayeh legends. These were regularly told or chanted around the fire or during communal work in the rice fields-some until relatively recently. The legend of Tuked Rini was no longer told regularly after World War II and was probably rarely told even in the first half of the twentieth century. This is probably because it was particularly closely linked to headhunting expeditions and these ceased around the turn of the nineteenth and twentieth centuries. Other legends survived until the late 1980s; the story of Agan Tadun was still being chanted in the rice fields while we were living in Pa' Dalih at that time. ${ }^{4}$

4 The first time any of the highland legends about heroes were recorded appears to have been when Tom Harrisson (1947-48) noted a small chanted fragment (sedarir; see below) of the legend of Tuked Rini as recited by Penghulu Miri. Guy Arnold (1956) noted a fragment of the legend of Tuked Rini during his visit to the Kelabit Highlands in 1956. In 1972, Carol Rubenstein, an American poet, recorded, transcribed and, with the assistance of Kelabit informants Masna Ulun and Lian Labang, translated versions of the legends of Tuked Rini (recited by Ngemong Raja) and those telling of two other heroes, Agan Ngadtang (recited by Niar Ayu) and Balang Lipang (recited by Inan Diu'). The legends as recorded by Rubenstein (1973: 807-1125) were included in a special issue of the Sarawak Museum Journal in 1973. My husband, Kaz Janowski, and I recorded the legend of Tuked Rini in 1986 (recited by Balang Pelaba) and I have transcribed and translated these with the help of Kelabit informants (Janowski 2014-16). A version of the legend of Tuked Rini as told by Rian John Pasan was also recorded by his daughter Cindy when she was at school (shortened version in Rethinasamy et al. 2013). Ricky Ganang recorded a version of the legend of Tuked Reminii, a Lundayeh hero equivalent to Tuked Rini, and an outline of the legend of Ufai Semaring (also known as Upai Semaring) in the 1970s, which he has transcribed (Ganang and Yansen 2018: 480-507 [Tuked Reminii]; and Ganang 2002: 26-27 [Ufai Semaring]). Kaz and I recorded versions of the legend of Agan Tadun (who is the same hero whom Rubenstein calls simply Agan) and that of Agan Tchan in 1987, both recited by Balang Pelaba. These have not yet been transcribed or translated. Rubin Jalla (who is Kelabit) has recently given me the outline of another Kelabit legend, that of Balang Lemudan, as told to him by his father, Penghulu Henry Jalla, when he was young, and as noted down by his sister Garnette Jalla and her son Ryan. This is not yet published. 


\section{Being heroic}

The legends about heroes function as projections of ideal humans and ideal human behaviour. They provide models to be emulated-in particular, models of male behaviour, because most of the central heroes are male. Legends about heroes have as their central characters one or several young men. Except for the legend of Tuked Reminii as recorded by Ricky Ganang, a major theme- even the main theme-of all of the legends is the adventures of young male heroes as warriors, telling of their headhunting expeditions and focusing particularly on their long battles with enemies, whom they always ultimately vanquish and kill. The legend of Agan Tadun-called Agan Ngadtang or simply Agan by Rubenstein (1973: 857-967) — has as an important thread the eventually successful meeting and mating of two young men and two young women, after complex adventures involving mistaken identities and lost children. However, this legend, too, includes a long description of a war expedition-the two young male heroes prove their mettle by battling with and beating two powerful enemies.

Male heroes are, then, the main focus of these legends, although female heroes are also key to the narrative. While the central achievement of the male heroes is to bring back heads from their expeditions, that of the female heroes is to grow and cook the rice and to make the rice beer that makes it possible to have the feasts at which the achievement of headhunting can be confirmed. At these feasts the heads are-in the legends and as they were in real life after a headhunting expedition-paraded by the women and then placed on huge bamboo poles erected outside the longhouse. The partnership of men and women means that the exercise of headhunting 'makes sense'; if the men had no women to whom to bring back heads and who could 'process' them through a feast, there would be no point in headhunting. This echoes the complementarity of men and women in constructing what I have described as rice-based kinship (Janowski 2007a, 2007b). The high status associated with heroes as male+female couples and the feast made possible through their complementary activities also echo the way in which the feeding of rice meals generates hierarchy among highland peoples (Janowski 2007a). Hero couples like Tuked Rini and Aruring Menepo Boong are of the highest status—-known as 'really good people' (lun doo to'oh). 
An important characteristic of heroes and of lun doo tooh - both male and female-is effectiveness. They are good at everything they touch. Men speak well, hunt well and carve wood and bone well; women also carve well, weave mats well, grow rice well and make delicious meals. Both male and female heroes are physically strong. Male heroes can jump and run huge distances, covering them in no time, making deep marks on the earth and on stones in the river as they do so. They have the stamina to keep going for aeons while battling with their enemies. The strength of female heroes is also emphasised; in the legend of Agan Tadun as recorded by Rubenstein, for example, a tall pole is erected made of a tree from which the bark has been stripped for female heroes to test themselves by climbing up to reach a jar full of rice beer and drink from it. Not all of the women of the longhouse can get up there; only female heroes (Rubenstein 1973: 906-09).

The effectiveness of heroes means they are natural leaders and models for the leaders of the people who used to tell and listen to the legendsand those who would become leaders. Heroes are able to care for all of their followers and ensure they have all that they need. Leading couples ensure that rice grows well, that there is plenty of hunted meat and that the longhouse is kept prosperous. Their people are described as anak adi ('young children'). Heroes are not only the leaders of their followers; they are also their 'parents' and 'grandparents'. Male+female hero couples lead longhouses-just as couples led longhouses in the real world-which are imagined as higher-level hearth groups (Janowski 1995, 2007a).

\section{Heroes and lalud}

Heroes - male and female-are perfect examples of humans. A hero is always beautiful and well-groomed according to ideas of the time-even when he has just returned from war:

Although he has just come back from fighting,

His hair is smooth and straight,

Cut in a straight line across his forehead,

Hair held over a sulungan gourd and cut with a knife.

His eyes are bright as damar lamps, like stars in the sky.

His eyebrows are plucked out, plucked with iron tweezers,

The thin skin above the eyes made clear.

His teeth are darkened in his mouth as it if were closed,

His upper gums a fine red color and his lower gums white. 
His ears are long and hanging,

And his earlobes swing forward in spirals below his neck.

He wears half of the moon for each of his earrings.

The moon shines bright and full from him all through the night

And during the day his earrings are the rays of the sun,

The brightest rays coming from beneath the sky.

(Rubenstein 1973: 859)

Female heroes are just as lovely. Here is the description Ngemong Raja gave of Aruring Salud Bulan, a woman who lives on the Moon and who, after a battle in which her husband is killed, marries the hero who has killed him, Iya Atul Aling Bulan, one of Tuked Rini's brothers:

She is a young girl lovelier than anyone can dream of, as if she is partly the daughter of Darayah [the Great Spirit; see below], by pure luck dropped from Within the Inner Moon. Light glows from her as from the sun as it moves among the spaces of the Highest Sky. Her headdress sends out rays as from a lamp set firmly on her head, crowning her with light. Like plaited sanguluh bands are the long slim loops of her earlobes; like tongs of bamboo, hammered flat and curved, are the long loops hanging far forward beneath her face. And each ear is hung full with one hundred earrings, all big and round. (Rubenstein 1973: 1043)

As this extract illustrates, heroes are beautiful because they have high levels of something that is described by the Kelabit and the Lundayeh as lalud. It is this that makes them effective. They are often described as shimmering with lalud (see Plate 5.1). Heroes wear lovely lalud-laden clothes. Female heroes wear shimmering magical cloths. As Aruring Menepo Boong, Tuked Rini's wife, says in Balang Pelaba's version of the legend: 'I wear a shimmering black bark cloth, like a developing, shimmering shadow [Klebong itm ko tonang angud lunging]' (Janowski 2014/16: 77).

Spirit tigers (balang), which have high levels of lalud because they are spirits (see below), are closely associated with male culture heroes, who wear cloaks made of their skins, sometimes said to be possessed by the tiger spirit itself - which follows the hero — and have headdresses incorporating the faces of tigers (Janowski 2014/16: 39-40, 42-43; Rubenstein 1973: 814, 867-68, 886). As Tuked Rini declares while preparing to depart for war, in Balang Pelaba's version of the legend (Janowski 2014/16: 42): 
Before I set off I put on my loose jacket as bright as the baking hot sun

I have put it over my chest

I will cover it with my tiger skin jacket with its wavy stripes

The skin covered with stripes, just like the highest sky, the Langit Temubong.
Ngan nalan sinayong ko sinayong lengu ko tso menotong

Senaro' pengaripen luun beropong

Pengaratah kulit barur lalikong

Kulit barur iring Langit

Temubong.

And here is Carol Rubenstein's translation of the description Niar Ayu, one of her informants, gave of Agan's preparations for his departure for war:

He puts on his tiger-skin cloak

With beautiful feathers attached to it

He places on his head his headdress

The cap of which is the face of a tiger,

Its face stretched so that its nostrils are big,

Its great fangs overhanging above and below,

Its eyes gleaming ...

The sound of Agan's footsteps can be heard

As he strides along the verandah,

And also heard is the calling sound

Of Ada' Akang, the spirit that rules the tiger-skin cloak,

Following along with Agan Ngadtang.

(Rubenstein 1973: 867-68)

Both men and women wear beautiful, valuable beads; beads are associated with status and themselves carry lalud (Janowski 1998). Here is the description Niar Ayu gave of Agan's beads:

His necklace is a bundle of strands,

Full of small white beads that look like bone,

His necklace that gleams also with rust-coloured alai beads,

Is rich with green alat bayung beads, beautiful to see,

With rare labang pagang beads,

And with lukut bala' beads bought from the Malay of Brunei.

(Rubenstein 1973: 859-60)

Things that possess high levels of lalud are described as malih (Ribuh Balang, Personal communication, 2009). Besides tiger-skin cloaks and headdresses and magical cloths, male heroes have weapons that are malih. Tuked Rini, in one of the chants (see below) that form part of the legend, tells of his knife that is so malih it is able to cause thunder to roll and blood rain to fall (Janowski 2014/16: 43): 
My sharp shiny knife

Which is so powerful that it causes thunder to roll and blood rain to fall

Which causes huge thunderclaps and rain to fall
Nawi retib tadim ken doo'sira

Nawi nok merurut leku'

udan dara'

Merurut udan leku'kora-kora

Male culture heroes are associated with many naturally occurring or worked stones in the highlands. It is said that it is only because they possessed such high levels of lalud that it was possible for these stones to have been deliberately moved and/or worked or inadvertently marked by them (through, for example, jumping from stream to stream). The size of such stones indicates to the people living now that heroes were giants. Near the current longhouse of Pa' Mada there is a huge block of stone that is said to have been Tuked Rini's whetstone, its size demonstrating that he was a giant (see Plate 5.3). There is another similar stone at Ba' Kelalan said to have been the whetstone of the culture hero Upai Semaring. Tuked Rini is said to have made marks on stones in the river when he was jumping across bends to reach places more quickly (see Plate 5.4) and to have made tracings on stone with his fingers, such as those made around the body of a spirit tiger that he is said to have hunted, laid on a stone and butchered (for full details of this story, see Janowski 2014/16: 51). The Lundayeh culture hero Upai Semaring is associated with a number of sets of stones that are said to have been his hearth stones, in Ba Kelalan and Long Pa Sia'. There is a bank of stones near Pa' Tik left by Balang Lipang (Ribuh Balang, Personal communication, 2009).

The heroes of the legends are often said to be able to transform into another form-something that is possible because of their high levels of lalud. In the version of Tuked Rini recited by Balang Pelaba, one of the heroes transforms into a tree trunk and falls on his enemies (Janowski 2014/16: 67); and in the version told by Ngemong Raja to Rubenstein, another hero, Iya' Utul Aling Bulan, transforms himself into rain to break through the roof of his enemies (Rubenstein 1973: 1026). Tagio Balang Pakaling Kuman, one of Tuked Rini's relatives who comes to help in the battle when called by Sinah Sepudau, is able to turn his hair into fire, which he throws at the enemy (Rubenstein 1973: 1051). The ability to transform from one form to another is a characteristic of powerful beings in Borneo; this is particularly evident in beliefs about powerful water snakes and dragons (Janowski In press). 


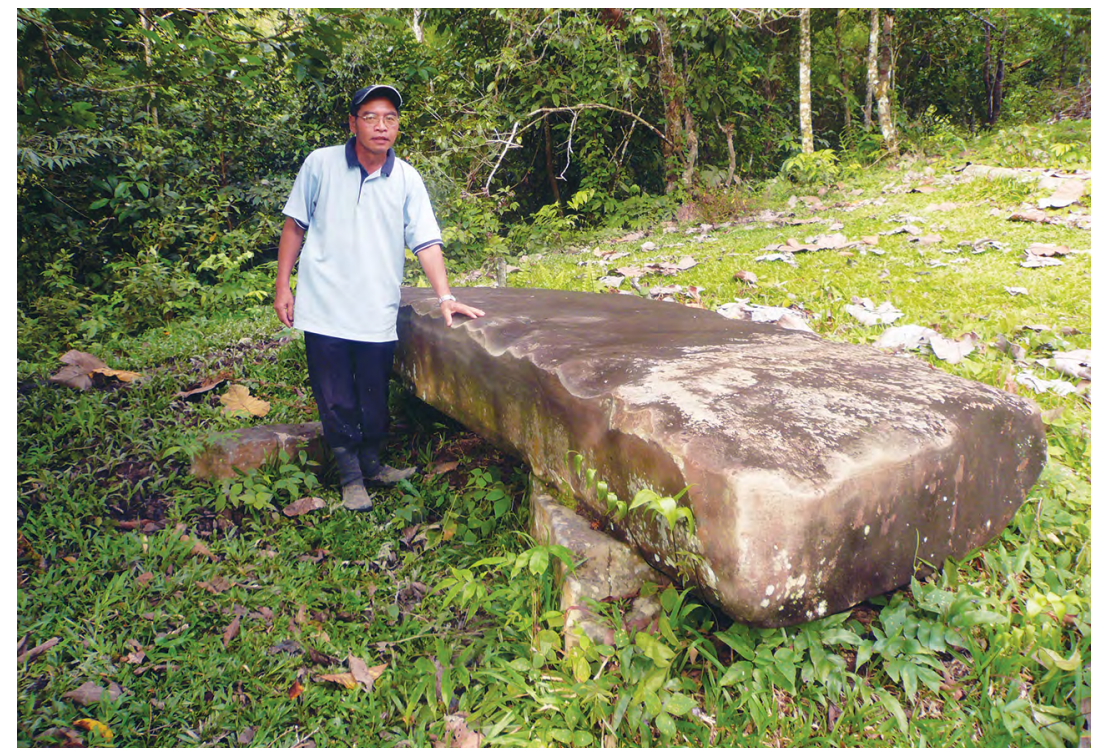

Plate 5.3 Baye Ribuh ('One Thousand Crocodiles') with Tuked Rini's sharpening stone (batuh iran Tuked Rini)

Photo: Monica Janowski, 2009.

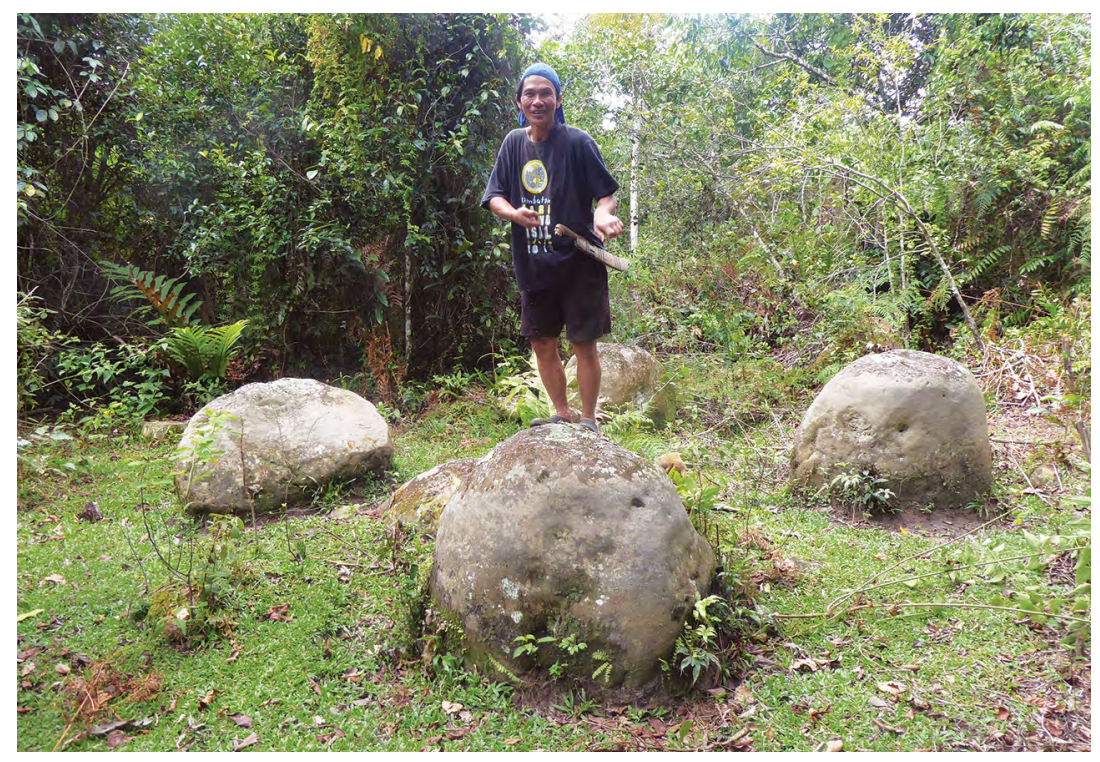

Plate 5.4 Kaya with giant batu angan (stones used to support a cooking pot over a fire) near Ba' Kelalan, which is said to have been used by the culture hero Upai Semaring

Photo: Monica Janowski, 8 August 2017. 
Lalud is cosmic power; it is also life force. As our neighbour Balang Pelaba, who recited the legend of Tuked Rini to me, once said to me: Kalau um eko lalud, um eko mulun ('If you didn't have lalud, you would not be alive'). Lalud is believed to be present throughout the cosmos to some degree; the cosmos, in other words, is essentially 'alive', as a whole. However, lalud concentrates in certain places. This includes not only beings that are biologically alive, but also certain stones, dragon jars and beads. It is concentrated in human leaders (Janowski 2012, 2016) and most particularly, heroes.

Lalud is closely associated with $a d a$, a term that can broadly be glossed as 'spirits' in English (Janowski 2012, 2016). Ada' are believed to be present everywhere, populating the cosmos. They are associated with concrete beings including plants, animals (including humans) and stones, but there are also free-floating $a d a^{\prime}$ not associated with any concrete manifestation. The less closely associated with a concrete being an ada' is, the more lalud it appears to be believed to have. Thus, the Ada' Raya or Deraya, the Great Spirit (Janowski 2014b, 2016), may appear in a semi-concrete form but is essentially pure spirit and may appear in any form he/she/it wishes-male or female, human-like or any other form. Transformation from one form to another and lack of attachment to a particular material form are, in other words, characteristics of $a d a^{\prime}$ with particularly high levels of lalud.

The heroes of legends like that of Tuked Rini are close to being $a d a$. They are semi-visible (see Plate 5.1) (invisibility is a characteristic of $a d a^{\prime}$ ) and they are able to transform into other forms, like $a d a$. We saw that Aruring Salud Bulan was described by Ngemong Raja as partly a daughter of Daraya; in the version of Tuked Rini recited by Balang Pelaba, Tuked Rini's wife, Aruring Menepo Boong, is described as 'partly human and partly a child of the Great Spirit, Derayeh, who inhabits the middle of the sky and the depths of the earth' (Janowski 2014/16: 34). Both males and females are described as being red (sia') - a colour associated with spirits among the Kelabit (Janowski 2014/16: 61; also see Rubenstein 1973: 809). Red is said to be the only colour that the spirits, including those of the dead, can see, and when the dead were taken to the megalithic cemetery in pre-Christian times a bracelet of ba'o sia' ('red beads') was placed on their wrists because this would enable the spirits to see them (Balang Pelaba, Personal communication, 1992). 
Not only the heroes of the legends but also those with whom they battle have high levels of lalud and are close to being $a d a$. They are described as beautiful in the same way as the main heroes are described. The heroes on both sides are well mannered and treat the battle as something between gentlemen, as it were; whenever battle is joined between them they first politely introduce themselves to one another. Thus, these battles are not between good and evil; they are between well-matched heroes with equal levels of lalud. Indeed, those on the other side are sometimes actually presented as possibly having higher levels of lalud; some of them have the word $a d a^{\prime}$ as part of their names. While all informants were always clear to me that heroes are not actually $a d a^{\prime}$, as you would not be able to see them if they were, the use of the word $a d a^{\prime}$ in a name implies high levels of lalud. This means that the achievement of our heroes in eventually beating them is the more remarkable.

Lalud (Janowski 2012, 2014a, 2014/16, 2016) belongs to a group of concepts in different languages and cultures in Southeast Asia referring to cosmic power or life force. I have addressed the implications of belief in such a power or force among the Kelabit and elsewhere (Janowski 1984, 1995, 2003a, 2003b, 2007a, 2007b, 2012, 2014a, 2016; Janowski and Kerlogue 2007; Janowski and Langub 2011). ${ }^{5}$ In Javanese, Anderson glosses kasektèn as 'power' or 'primordial essence' (1972). In Balinese, the equivalent term is sekti, which Geertz describes as 'charisma' (1980). In Malay, the term semangat can be glossed as 'a vital or effective force' (Winstedt 1956: 19) or 'spirit of life' (Laderman 1991: 41-42). Among the Luwu (Sulawesi), a cognate term is used, sumangé, which Errington glosses as 'potency' (1989). Among the Ao Naga, the term aren refers to what Mills called 'life force' (1926: 112). Geertz (1980: 106) has argued that the Balinese concept of sekti may be equated with the Polynesian concept of mana; and Barbier has argued that the Batak notion of sahala is also equivalent to mana (1999: 86). The belief in an all-pervading vital force is a fundamental one in the region. This group of ideas about something that is both cosmic power and life force connects upland and lowland, mainland and insular Southeast Asia (Århem 2016). The significance of belief in a vital force was recognised in early ethnographies of insular Southeast Asia, such as Skeat's book on Malay magic (1900) and Kruyt's book on animism (1906). There has also been recognition of

5 Although Needham (1976) has argued against any belief in such a life force in Southeast Asia, this is on the (in my view, mistaken) basis that such a belief would necessarily be grounded in a 'Western'-style notion of causality. 
the importance of belief in this force on the part of researchers working more recently in both mainland and island Southeast Asia (for example, Benjamin 1979; Endicott 1970; Fox 1987; Kirsch 1973).

\section{Bringing back lalud: The importance of return}

Vital force is believed to flow, and it can be lost and gained. Loss or gain of it is regarded as central to establishing levels of bodily strength, effectiveness in activities and enterprises, social and political success and levels of spiritual strength. Thus, there is a constant struggle to gain more of it and to prevent loss of it.

The journeys made by Kelabit heroes out into the cosmos, to fight with enemies and take their heads, have as their goal not only the expression of lalud, through successful battles, but also, as we shall see, the capture of lalud and its return to Luun Atar. The journeys made out into the cosmos always end with return. This is underlined in legend as recited by Tuked Rini, who tells of how the lesser people who have died in the battle inside the Spirit Tiger Rock, and who are in a part of the cosmos where the dead go, are persuaded to return to Luun Atar. As two of the lesser people, Lang Kuang and Merigang, tell the others, who are arguing that in the place of the dead where they are everything grows better than in Luun Atar: 'Even if Luun Atar were really such a dreadful place, it's where our ancestors were born, and we should return' (Janowski 2014/16: 72).

\section{The structure of the legend of Tuked Rini: A narrative anchored in lalud-laden chants}

The main body of the legend of Tuked Rini is related by the storyteller in a normal voice, using his own words. It includes humorous anecdotes, including ones relating to those who are listening. When Balang Pelaba recited the legend in 1986, in my presence and that of many residents of Pa' Dalih where I was living at the time, he incorporated a number of humorous anecdotes (not included in the outline above, for brevity), including one involving me.

However, the body of the narrative of the legend is anchored to a string of chants, which are central to the legend. The chants are recited at key points along Tuked Rini's journey with his close kin and followers. By contrast with the main body of the story, they are recited in a sing- 
song voice. Also by contrast to the main body of the story, they are learnt by heart, passed from teller to teller (which means they are often very difficult to understand and translate as they are not only in archaic language but also have been somewhat transformed through the process of 'Chinese whispers').

In the legend of Tuked Rini as recited by Balang Pelaba, there are six chants: four recited by Tuked Rini and two by his wife, Aruring. In the version recited by Ngemong Raja there are 10: five recited by Tuked Rini, three by his brother Agan Bulan Makub Lungung, one by his brother Iya' Utul Uling Bulan and one by Aruring Salud Bulan, a lady living originally on the Moon who eventually marries Iya' Utul Uling Bulan. ${ }^{6}$ These chants are only present in the legend of Tuked Rini; they are not part of any of the other legends of which we have a record.

The chants—which can be seen as parallel to beads, which the Kelabit traditionally regarded as both precious and powerful (Janowski 1998) are not necessarily strung in the same order through the legend. It seems that there was originally a considerable repertoire of chants relating to Tuked Rini, his fellow heroes and their wives. They have sometimes been recited on their own. ${ }^{7}$ Different tellers chose different chants and strung them in different orders, presenting the sequence of the journey of Tuked Rini and his fellows differently in consequence.

Chants are described as being dalim ('deep'), as are many of the words used in them. This means that the words themselves, as well as the combinations of words within the chants, carry lalud. The words and phrases themselves make things happen. They make the person reciting them able to achieve what he/she is about to do (Ribuh Balang, Personal communication, 2009). They declare the possession of lalud on the part of the heroes chanting them, and they draw on that lalud to utilise it, particularly before battle on the part of the male heroes:

I will make a powerful and effective man's kit call

My call will fill the whole world, under the Highest Sky, the Langit Temubong,

It will chase the children [a metaphor for enemies] playing under the olong pole. (Janowski 2014/16: 60)

6 I was told that these are called sedarir, Rubenstein describes them as nadadir (1973: 967).

7 Penghulu Miri recited one chant to Tom Harrisson (1947-48) and Ribuh Balang recited several to me. 
The meaning of the words and the combinations of words are not fully comprehensible to the audience or even the teller. Balang Pelaba was only partly able to explain the meaning of the chants he had recited to me. Younger people found it very hard to understand the bulk of the chants. This means that my translation of the chanted parts of the story (Janowski 2014/16) is much more tentative than that of the rest of the legend.

\section{The cosmos-scape of Tuked Rini's journey}

The cosmos-scape within which the journey and battles of the legend take place seems to be in some respects laid over the real world in which the people of the highlands live. According to Balang Pelaba and others from the Kelapang River who discussed the legend of Tuked Rini with me, the site of the longhouse led by Tuked Rini, Luun Atar, is at the mouth of the Mada' River, where it flows into the main Kelapang River. This is the current site of a longhouse called Pa' Mada. The site is one of a string of sites along the Kelapang River where there is physical and/or orally related evidence of settlement. Through the recent interdisciplinary Cultured Rainforest project, for which I led the anthropological component, we now have physical evidence from earth cores and/or archaeological excavation for some of these sites that they have been the focus of settlement for centuries - and some at least for millennia (Barker et al. 2008, 2009; Lloyd-Smith et al. 2010, 2013). Many of them, including Pa' Mada (Luun Atar), are places where there are palaeochannels of the river that have been used for rice cultivation for the past 400 years or so and which may well have been used for wet taro cultivation long before that (Barker et al. 2008, 2009). Thus, there is a deep cultural link between the cosmos-scape in which Tuked Rini lived and travelled and that in which the people of the highlands themselves live. The two are overlaid one on the other. I should note here that in other parts of the area inhabited by the Kelabit it is said that Tuked Rini did not live in the Kelapang area but elsewhere; in the community of Long Lellang, it is said that he lived in a longhouse near the Pa' Adang, in the shadow of the great stony mountain of Batu Lawi (Rubin Jalla, Personal communication, 2019).

However, although they are rooted in a landscape that is shared with and accessible to people living in the world now, Tuked Rini and his fellows travel to places that are outside the known and accessible parts of the cosmos. In both Balang Pelaba's and Ngemong Raja's versions of the legend, Tuked Rini and his fellows travel into the interior of a huge 
rock and do battle with people living there. Ngemong Raja calls this the Huge Rock (Batuh Agong), while Balang Pelaba describes it as the Vastly Tall and Powerful Spirit Tiger Rock (Batuh Balang Tekinang Lungung). ${ }^{8}$ In Balang Pelaba's version, the heroes do battle with the Spirit Tiger Rock before forcing it below the ground and entering it to find the people living inside and do battle with them (Janowski 2014/16: 48-61). In Ngemong Raja's version of the legend, they also travel to a number of places in the sky, to the Moon and deep under the earth. ${ }^{9}$ The legend of Tuked Rini is the only legend in which the heroes travel to such places; in the other Kelabit legends mentioned above, they remain within the known and easily accessible parts of the cosmos.

In travelling, heroes in all of the legends travel, drawing on their lalud, much faster than normal people-leaping, for example, over bends of rivers. In the process, the heat and power of their lalud leave marks such as that on a stone in the bed of the Kelapang River near Pa' Dalih, which I was told had been made by Tuked Rini (see Plate 5.4). In the legend of Tuked Rini, he and the other heroes do not just leap; they also often fly to their destinations. Other heroes drop down from the sky to join Tuked Rini in the battle inside the Spirit Tiger Rock (Janowski 2014/16: 64). The lesser people of Luun Atar, however, cannot fly. They hang on to Tuked Rini's brother's sword sheath when he leaps into the air to fly to the Huge Waterfall (Janowski 2014/16: 45). In flying, the heroes display high levels of lalud.

The places to which heroes journey in the legend of Tuked Rini are places that are lalud-laden-loci of lalud within the cosmos-scape. Here, they do battle with heroes who are semi-spirit, and with beings that are not human at all, such as the Spirit Tiger Rock. Travel to such places and doing battle with beings there not only demonstrate the possession of lalud, but also allow heroes to gather large amounts of lalud through vanquishing their opponents. They take this lalud back home to Luun Atar in the form of the heads of their enemies.

8 I was told by another elderly informant who recited some of the chants in the legend of Tuked Rini to me that Ngemong Raja had forgotten the full name of the Rock, which should indeed be Batuh Balang Tekinang Lungung (Ribuh Balang, Personal communication, 2009).

9 Rubenstein calls this place - to which the captured hero Aruring Salud Bulan is taken and from which she is rescued by Tuked Rini, Iya Atul Aling Bulan and other heroes from Luun Atar-Puruk Panah Liang, which she translates as 'Within the Inner Moon' (Rubenstein 1973: 968). However, other informants have told me this should be Puruk Tanah Liang and that it is not inside the Moon but should be translated as 'Deep Under the Earth' (David Labang and Ribuh Balang, Personal communication, 2009). 


\section{Headhunting and lalud}

The purpose of the journeys made by Tuked Rini and his fellows is to do battle and to take heads, carrying lalud, back to Luun Atar. Headhunting was central to the culture and cosmology of the Kelabit until they became Christian from the 1950s. While the Kelabit did not engage in headhunting as often as did some other peoples_-particularly the Iban, who were rapidly expanding across Sarawak in the eighteenth and nineteenth centuries and taking heads as they went-headhunting occurred sporadically as part of the feuding that was endemic in the highlands for centuries until Rajah Charles Brooke, the second 'white Rajah' of Sarawak, brought an end to this at the beginning of the twentieth century. Kelabit settlements in the Kelapang Valley, where I have done most of my fieldwork, were often not sited along the main river, despite the fact that this was where the small wet fields in which most of the highly prized rice was almost certainly grown until 300 or 400 years ago, but on ridges above the river. This was for defence against headhunting attacks (Barker et al. 2008: 143).

The reasons for headhunting have been discussed in anthropological literature since Hutton and Kruyt first tackled the topic in the early twentieth century (Hutton 1928; Kruyt 1906). While other reasons for taking heads have been put forward and there has been a tendency in recent years to conclude that there may be multiple reasons for headhunting (see chapters in Hoskins 1996a), many scholars have argued that heads bring fertility or life force into communities (Davison and Sutlive 1991; Freeman 1979; Hoskins 1996b, 1996c; Hutton 1928; Izikowitz 1979; Kruyt 1906; Needham 1976). For the Kelabit, as for many other peoples in Borneo (for example, Metcalf 1982; Uchibori 1978), heads were necessary to bring to an end the period of mourning after a death, particularly where the death was that of a leading individual. Such an individual was not taken to the cemetery for a long period after death. ${ }^{10}$ It is likely that the reason for headhunting associated with death, particularly that of an important person, is that heads were believed to bring lalud into the community - a fresh source of vitality to replace that lost through the death.

10 According to Balang Pelaba of Pa' Dalih, who was previously a shaman (dayong) and was centrally involved in dealing with the dead when he was young, the Kelabit practised secondary disposal of the dead for all those who died as respected adult members of the community, keeping them in the longhouse until the flesh had rotted off their bones. A series of irau feasts was held to commemorate them and to send them off for good (Balang Pelaba, Personal communication, 1992). 
Heads taken in headhunting were treated as kin, feted when they arrived, fed and cared for. The importance of recruiting enemy heads as friends is something pointed to by researchers working in other parts of Southeast Asia (McKinley 1976; Mills 1935). Proper care of the heads meant that their spirits (ada 'in Kelabit) were kept friendly and helpful, protecting the longhouse and adding to the sum total of lalud present in the community. It was considered very important to continue to feed them, as their spirits could become angry and vengeful against the community if they were not cared for properly. This is a widespread belief in Borneo, and remains strong. ${ }^{11}$ While the Kelabit no longer keep any heads, as they have become keen evangelical Christians and have discarded them all, some people within other tribal groups, including the Iban and the Bidayuh, continue to keep heads and to use them for ritual purposes. I even know of individuals who have brought old heads to keep in their houses in town, believing that this will make their lives more successful.

After a headhunting expedition, heads were taken back to be handed over to the wives of headhunters; the relationship between Kelabit husband and wife was central to the processing of the lalud brought back in heads. The wife of a warrior, receiving heads he has taken, is as lalud-laden, as spirit-like, as her husband. She is semi-visible, like a spirit; she is red, the colour of the spirits. As Tuked Rini says:

I will string the fish [a metaphor for enemy heads] on kusah rottan

I will give them to the sparkling red lady to carry

The well-known lady who shimmers like a rainbow

The well-known lady like a shining rainbow, sometimes visible, sometimes not. (Janowski 2014/16: 60-61)

The relationship between headhunting husband and head-receiving wife may, I would suggest, be seen as parallel to that which I have argued exists between them in their roles as providers of the rice meal to their dependants; as a wife processes the lalud brought in through the hunting of meat by bringing it together with rice at the rice meal (Janowski 2007a), so she may be seen as processing the lalud brought in through the hunting of heads.

11 When the heads present in the old building of the Sarawak Museum, hanging in reconstructions of parts of longhouses belonging to different ethnic groups, were moved out of the building in October 2016, a miring ceremony was held (at which I was present) to appease the spirits of the heads. There was serious concern among museum staff about the possibility that there would be problems otherwise. I was told of this concern by Dora Jok, the head of the Ethnography Section and in charge of the ethnographic collections (Dora Jok, Personal communication, October 2016). 


\section{Bringing back discarded children: Repatriating lalud}

There is another way in which lalud may be regarded as being brought home as part of the legends. This is through the repatriation of what are known as anak na'ol ('discarded children'). These are children who have been exposed to die at birth because they were born at a time that was inconvenient-for example, because they were born during the rice harvest, during a visit to another place or because they were considered unlucky or dangerous, such as if they were twins. In the legends of Tuked Rini and of Balang Lipang, the heroes from Luun Atar encounter other heroes who turn out to be anak na'ol from Luun Atar. Sometimes, as in the legend of Tuked Rini as recited by Ngemong Raja, other heroes brought in to fight with the main heroes by Sinah Sepudah (= Sinah Sepudau in Balang Pelaba's version-see above) immediately declare themselves to be anak na'ol and Tuked Rini's first cousins, join straight away in battle alongside Tuked Rini and go on to prove themselves good fighters (Rubenstein 1973: 990-91). In the legend as recited by Balang Pelaba, the heroes brought to fight with Tuked Rini by Sinah Sepudau are not anak naol, though they are kin to Tuked Rini, but the theme of anak na'ol is present here, too: Tuked Rini and his fellow heroes first battle at length with other heroes, finding them worthy opponents, before the Great Spirit Mother, Sinah Purid Derayeh, informs them that they are kin because those they are fighting are anak na'ol from Luun Atar (Janowski 2014/16: 69). In the story of Agan Ngadtang as recited by Niar Ayu, anak na'ol also appear: Agan encounters, fights alongside and eventually brings home his brother, Lian Aran Ngadtang Balang, another anak na’ol (Rubenstein 1973: 901). Lian, like his brother Agan, is a great fighter. Anak na'ol also appear in the legend of Balang Lipang as recited by Inan Diu': Balang Lipang encounters his father's brother, Pun Anan, who turns out to be an anak na'ol (Rubenstein 1973: 822). Pun Anan is a smith who transforms Balang Lipang into an invincible iron man who goes on to vanquish his foe. Balang Lipang eventually takes Pun Anan back home to be re-united with his brother, Balang Lipang's father.

All of these anak na'ol have a great deal of lalud. They return home in the end-along with their lalud. Thus, these stories of repatriating anak na'ol are also stories of repatriating lalud. 


\section{Getoman ngan lalud: 'Joining with power'}

The high levels of lalud displayed, drawn on and gathered by heroes relate to the fact that they are said to be in a state of getoman ngan lalud or 'joining with power'. This is a mysterious and fascinating concept. It is not clear whether this term refers to a time in which the heroes live or to the condition of their lives; perhaps it refers to both. In the sense that it refers to a time, this does not appear to be situated in an entirely chronological relationship with the present. There is a sense in which it is situated in a time long ago, ancestral to the present-but a time not connected in any direct way with the present. Balang Pelaba saw getoman lalud as a context at the beginning of time in which humans were closer to God: 'Our ancestors at the beginning were linked to lalud ... they were very close to God and to Jesus. Jesus gave them lalud [Lun merar let puun puun getoman ngan lalud malem ... moneng moneng ngan Tuhan Allah, ngan Tuhan Jesus. Tuhan Jesus mre lalud ngan idah]' (Personal communication, 1988). Getoman ngan lalud is in a sense, then, a time in the mythical past. It is an idealised version of the real world-what it once was.

Getoman ngan lalud is also what could be if people behaved as they should. In some sense, getoman ngan lalud also exists now. Some Kelabit men living in town have shown a good deal of interest in the legend of Tuked Rini, seeing it as exemplifying the way in which humans, and particularly men, should live. In other words, getoman lalud remains as a possibility. Some men say that they aim to live it out in their own lives, in the sense that they are living to their full potential as the heroes did, using all their powers (Lian Labang, Personal communication, 1989; Rubin Jalla, Personal communication, 2019). Perhaps we can see getoman lalud as somewhat similar to the semi-spirit world of Panggau Libau in which Iban heroes are said to live, which is said to coexist with the world in which normal Iban live (Kedit 2009).

In a state of getoman ngan lalud, lalud is very evident and is expressed through the heroes of the legends who exist in this state. The heroesbeautiful, lalud-laden giants-possess much more lalud than humans do now, making them able to do things humans cannot do and travel to places to which normal humans cannot travel. When heroes drop down on to the earth from their flights across the cosmos, thunder roars, lightning flashes and blood rain falls (Rubenstein 1973: 980-81, 990, 993, 1011, 1012). They have, as we have seen, powerful possessions, including knives (which also cause thunder, lightning and blood rain) 
and clothing derived from the balang or spirit tiger. In Balang Pelaba's version of the legend, Tuked Rini is said to have done battle-both in the legend and in a tale told to me separately (Janowski 2014/16: 51) —with a spirit tiger. Tigers are considered to be possessed of great cosmic power throughout Southeast Asia (see, for example, Hutton 1920; Sellato 1983; Wessing 1986). In Borneo, where there are no material tigers, they are by definition spirits (in Kelabit and Lun Bawang, $a d a^{\prime}$ ). Spirits are considered to be particularly powerful-more so than beings that exist in material form. In the legend, the spirit tiger is a being called the Batuh Balang Tekinang Lungung ('Hugely Tall and Powerful Spirit Tiger Rock'). This being is both rock and spirit tiger. Stone is believed throughout Southeast Asia to be a repository of cosmic power/life force (Janowski 2020).

\section{Seeking getoman ngan lalud in the modern world}

Lian Labang, who left the highlands in 1948 to go to work at the Sarawak Museum, declared to me: 'Tuked Rini is in my life [Tuked Rini lam dueh ulun]' (Personal communication, 16 November 1992). In other words, he, in his own life, was living out a modern version of the heroic journey of the legend. He, like Tuked Rini, had ventured out of the highlands into the cosmos beyond, seeking adventure and success. For Lian, in making airplanes, in making journeys to the Moon, we are doing the same thing as Kelabit heroes like Tuked Rini and Agan Tchan. The essence of being a hero is exploration, finding out new things, going where no-one has been before.

Lian was followed in his journey out of the highlands to town by a number of Kelabit, who left the highlands in the 1960s and 1970s to enter secondary education. A significant number of them went on to higher education and became very successful. They, like Lian Labang, are in some sense equivalent to the heroes of legends like that of Tuked Rini. They have journeyed out into the cosmos, expressed their own lalud through their success and accumulated lalud-not through head-taking but through their achievements. They are regarded by other Kelabit as potentially powerful centres of lalud. When Idris Jalla from the community of Batu Patong became a federal minister, prayers were offered within the Sidang Injil Borneo Church for his wisdom and that he might become a 'Joseph' (an Israelite who, according to Genesis, was sold into slavery in Egypt but nevertheless became vizier of that country) representing the Kelabit and other Orang Ulu (Dora Jok, Personal communication, 28 February 2019). 
It is the Kelabit belief that they have gained privileged access to lalud through their adherence to Christianity. It is very common to hear urban Kelabit attribute success in education and in getting good jobs to Christianity. In headhunting times, lalud was sought through shamanic relationships with spirits (Janowski 2016), through friendships with the Great Spirit in its male form as the Ada' Raya or Puntumid (Janowski 2014b) and through headhunting. Now, the Kelabit regard Christ as their source of lalud. The Kelabit have been keen to make a 'break with the past' (Lian-Saging 1976-77: 211) and this relates in particular to their adoption of Christianity after World War II. Particularly since the 'Revival' of 1973 (Bulan and Bulan-Dorai 2004), the Kelabit have abandoned relationships with spirits and previous beliefs and practices. At the Revival, they discarded all of the heads taken in headhunting raids in the past. They rely entirely on Christianity, practising a fundamentalist variety as part of the Sidang Injil Borneo Church. Amster (2009) has argued that Christianity allows them to have more 'portable' potency; this makes sense in the context of the fact that most of the Kelabit now live on the coast.

The Kelabit concern with seeking and accumulating lalud is part of wider concern in the region with gathering vital force-one that was important not only in the past but also continues to be important in the present. The successful concentration of vital force is associated with and leads to concentrations of people and the growth of political centres, eventually leading to the development of small states. As Walker has pointed out, 'leadership and power derived from the fact that semangat, as potency, could be infused to differing degrees, with individuals ranking themselves according to the amount of potency they possessed' (2002: 18). Headhunting - intended to concentrate vital force-was practised not only by small-scale societies, but also by states (McWilliam 1996; Maxwell 1996). In other words, the transition from 'tribal' to 'state' does not mean that it ceases to be important to concentrate vital force. Attempts to concentrate vital force, as well as the belief that important, charismatic leaders are indeed a concentration of vital force, continue into the present day. As Walker puts it: 'Semangat is charisma, localised' (2002: 18). Anyone who has lived anywhere in the region will have heard stories about concentrations of powerful objects and bomoh around political leaders in the region. 
Thus, it should be no surprise that incorporation into the 'modern' urban world does not mean that tribal people like the Kelabit abandon an interest in accumulating and gathering lalud. They continue to seek getoman ngan lalud. However, the dynamics of accumulation and the personal significance and social contextualisation change radically. Individual Kelabit spend a good deal of psychological and emotional effort trying to deal with the complexity of these dynamics.

\section{The hero in the present day: No return}

Tuked Rini's journey was circular; it ended with his return to Luun Atar, bringing back lalud to feed into his home community. Nowadays, however, successful Kelabit do not return to the highlands after they have completed their education; they look for work outside the highlands. To stay in the highlands as a young person is, in fact, to be a failure. Some Kelabit do eventually retire to the highlands to live permanently. A larger number build a house in the highlands and spend part of their time there. Increasing numbers look likely, however, to spend the rest of their lives outside the highlands, near their children, who would not countenance any more than short holidays in the highlands-somewhere they have never lived.

Thus, present-day heroes do not return. The journeys of modern-day Kelabit heroes are not circular. The lalud they accumulate is not taken back home. The powerful centres that heroes create are physically located in town, and even in foreign countries, as many have moved abroad.

This lack of return is problematic at various levels. Town-based Kelabit themselves feel that they have lost something vital because they no longer live in the highlands. They are nostalgic about their lives there as children. An important part of this nostalgia is for the loss of the feeling, living in a longhouse, that they were part of a bigger community in a way that is impossible in town. Another significant loss is of contact with nature. This has been expressed in recent years in a series of conversations on a Kelabit Facebook group in which young men have toyed with the idea of trying to make contact with the Great Spirit, Ada' Raya, also known as Puntumid ('Grandfather Heel') (Janowski 2014b). 
The lack of return also has implications for the relationships between leaders and others. In the past, leading couples like Tuked Rini and Aruring Menepo Boong were at the very core of their longhouse. Longhouses were rebuilt every few years and the leading couple, the lun doo to'oh ('very good people'), would lead the rebuilding, building their hearth at the centre with close kin on each side and more distant kin further along the longhouse at each end. They were responsible for all of the enterprises in which the people of the longhouse engaged. The lady of the couple led the rice growing, making the biggest fields with the help of others and taking responsibility for ensuring everyone, including visitors, was fed. Her husband led the men in hunting, ensuring that there was adequate meat to feed everyone. The lalud of a leading couple in the past was at the service of others. The lalud brought back from headhunting, led by the leading man of the longhouse, fed into the pool of lalud held by the whole community and benefited all.

In town, things are very different. Nowadays, a successful couple does not lead a longhouse or take responsibility for the daily lives of others. Life in town makes this impossible; success in the urban world is individual success and tends to benefit the immediate family rather than a wider group. This means that the relationship between successful people and other Kelabit has changed. In the past, being of high status among tribal people in Borneo meant profound respect-even what has been described to me as 'adoration', among the Kayan (Dora Jok, Personal communication, 28 February 2019). Nowadays, this is no longer true. Arguably, this is because those who gather lalud are not seen to be taking it back to benefit the wider group from which they come. The Kelabit are, I was told by a town-based Kelabit, losing their lalud as a community (Robert Lian-Saging, Personal communication, 27 February 2019). I think this remark reflects a sense that the Kelabit community has been dispersed and the Kelabit identity is being lost; those in the highlands are fewer and fewer and those in town are being absorbed into a multi-ethnic town community.

\section{Conclusion}

I have argued that the Kelabit quest for lalud is central to understanding the significance of Kelabit legends about heroes. Lalud as a concept is central to all Kelabit legends, but particularly to that of Tuked Rini, strung as it is in the form of a series of lalud-laden chants, like precious beads. 
Lalud belongs to a family of concepts important throughout the region relating to ideas about vital or cosmic force. Heroes like Tuked Rini and his wife, Aruring Menepo Boong, have high levels of lalud. This means they have the highest status - they are lun doo to'oh ('really good people'). They are ideal humans, more beautiful and effective than their fellows, able and willing to lead and care for their kin and dependants. Not only do they possess lalud; male heroes like Tuked Rini also seek lalud. They go out journeying across the cosmos to seek lalud, visiting lalud-laden places and doing battle with worthy enemies, who are themselves heroes representing other communities. In bringing back the heads of these enemies, they bring back lalud to their communities. Heroes feed this into their communities through their relationships with their wives, via the same mechanism I have explored elsewhere in relation to the rice meal (Janowski 2007a).

The journeys of heroes like Tuked Rini are expressions of exploration and curiosity, displaying willingness to try new things and go to new places. In the same spirit, the Kelabit took up the opportunity to enter into the wider world through education, when this became available from the 1950s. However, I have suggested that the journey on which these young people embarked led them to a place they had not quite bargained for. It led them away from their origins and essentially barred the way to any return to the life they had left. They had entered another world with a different structure and radically different values from the one they had left. The new world of the town does not allow for leadership and heroism of the old kind. It does not allow for a clear mechanism for them to feed the lalud they built up in their journey towards success back into their home communities. Their journeys are not, then, circular as were those of Tuked Rini and the other male heroes of the legends. They are linear, onwards and upwards—-but with no clear destination.

I want to return here to the quote with which I began this chapter. The heroes of the legends, like those Kelabit who have taken up opportunities in town, take a journey into the wider world. Such a journey into the unknown carries with it a journey into oneself. The heroes of the legends find themselves in the collective, in the group of kin to which they belong. In accumulating and bringing back lalud through their journeys, they were building up their home longhouse as a lalud-laden centre. While they, as high-status lun doo to'oh, were at the core of that centre, it did not stop with them. It included all of the people who lived with them, their enspirited heirlooms (pusaka) and also, most probably, 
the rice spirits that coexisted with humans. Kelabit who have made the journey to success in the world outside the highlands also try to find themselves in the collective, in the community, placing importance on themselves as embedded at the centre of a wider Kelabit grouping seen as kin. But without a return to the highlands, without living at the centre of a longhouse, the location of that collective, of that belonging, is proving hard to find.

\section{References}

Amster, Matthew H. 2009. 'Portable potency: Christianity, mobility and spiritual landscapes among the Kelabit.' Anthropological Forum 19(3): 307-22. doi.org/ $10.1080 / 00664670903278429$.

Anderson, Benedict R.O'G. 1972. 'The idea of power in Javanese culture.' In Claire Holt with Benedict R.O'G. Anderson and James Siegel, eds, Culture and Politics in Indonesia, pp. 1-69. Ithaca, NY: Cornell University Press.

Århem, Kaj. 2016. 'Southeast Asian animism in context.' In Kaj Århem and Guido Sprenger, eds, Animism in Southeast Asia, pp. 3-30. London: Routledge. doi.org/10.4324/9781315660288-1.

Arnold, G. 1956. Unpublished field diary from visit to Kelabit Highlands in 1956.

Barbier, Jean Paul. 1999. 'Batak monuments: In the shade of the petrified ancestors.' In Jean Paul Barbier, ed., Messages in Stone: Statues and sculptures from tribal Indonesia in the collections of the Barbier-Mueller Museum, pp. 79-155. Milan: Barbier-Mueller Museum and Skira.

Barker, G., H. Barton, D. Britton, I. Datan, M. Janowski, J. Langub, L. LloydSmith, B. Nyiri and B. Upex. 2008. 'The Cultured Rainforest project: The first (2007) field season.' Sarawak Museum Journal LXV(86)(NS): 121-90.

Barker, G., H. Barton, E. Boutsikas, D. Britton, B. Davenport, E. Ewart, L. Farr, R. Ferraby, C. Gosden, C. Hunt, M. Janowski, S. Jones, J. Langub, L. LloydSmith, B. Nyiri, K. Pearce and B. Upex. 2009. 'The Cultured Rainforest project: The second (2008) field season.' Sarawak Museum Journal LXVI(87) (NS): 119-84.

Benjamin, Geoffrey. 1979. 'Indigenous religious systems of the Malayan Peninsula.' In A.L. Becker and Aram Yengoyan, eds, The Imagination of Reality: Essays in Southeast Asian coherence systems, pp. 9-27. Norwood, NJ: Ablex. 
Bulan, S. and L. Bulan-Dorai. 2004. The Bario Revival. Kuala Lumpur: HomeMatters.

Davison, J. and V.H. Sutlive. 1991. 'The children of Nising. Images of headhunting and male sexuality in Iban ritual and oral literature.' In V.H. Sutlive, ed., Female and Male in Borneo: Contributions and challenges to gender studies, pp. 153-530. Williamsburg, VA: Borneo Research Council.

Endicott, Kirk. 1970. An Analysis of Malay Magic. Singapore: Oxford University Press.

Errington, Shelly. 1989. Meaning and Power in a Southeast Asian Realm. Princeton, NJ: Princeton University Press. doi.org/10.1515/9781400860081.

Fox, James J. 1987. 'Southeast Asian religions: Insular cultures.' In M. Eliade, ed., The Encyclopedia of Religion. Volume 13, pp. 520-30. New York: Macmillan.

Freeman, J.D. (Derek). 1979. 'Severed heads that germinate.' In R.H. Hook, ed., Fantasy and Symbol: Studies in anthropological interpretation, pp. 233-46. London: Academic Press.

Ganang, Ricky. 2002. Laba' em idi serita' luk mekemu' [Myths, Legends and Short Stories]. Self-published.

Ganang, Ricky and T.P. Yansen. 2018. Dayak Lundayeh idi Lun Bawang. Budaya serumpun di dataran tinggi Borneo [The Lundayeh and Lun Bawang Dayak Peoples: The culture of the indigenous peoples of the highlands of Borneo]. Palangka Raya, Kalimantan Selatan, Indonesia: Lembaga Literasi Dayak.

Geertz, Clifford. 1980. Negara: The theatre state in nineteenth century Bali. Princeton, NJ: Princeton University Press.

Harrisson, T. 1947-48. Kelabit Songs and Sekono and Heads. Malaysian National Archives, Accession no. 2006/0035307.

Hoskins, Janet, ed. 1996a. Headhunting and the Social Imagination in South East Asia. Stanford, CA: Stanford University Press.

Hoskins, Janet. 1996b. 'Headhunting as practice and as trope.' In Janet Hoskins, ed., Headhunting and the Social Imagination in Southeast Asia, pp. 1-49. Stanford, CA: Stanford University Press.

Hoskins, Janet. 1996c. 'The heritage of headhunting: History, ideology, and violence on Sumba, 1890-1990.' In Janet Hoskins, ed., Headhunting and the Social Imagination in Southeast Asia, pp. 216-48. Stanford, CA: Stanford University Press. 
Hutton, J.H. 1920. 'Leopard-men in the Naga Hills.' Journal of the Royal Anthropological Institute 50: 41-51. doi.org/10.2307/2843373.

Hutton, J.H. 1928. 'The significance of head-hunting in Assam.' Journal of the Royal Anthropological Institute 58: 329-413. doi.org/10.2307/2843630.

Izikowitz, Karl Gustav. 1979. Lamet: Hill peasants in French Indochina. New York: AMS Press.

Janowski, Monica. 1984. 'Chieftainship among the Naga of north east India.' MPhil dissertation, University of Cambridge, Cambridge.

Janowski, Monica. 1995. 'The hearth-group, the conjugal couple and the symbolism of the rice meal among the Kelabit of Sarawak.' In Janet Carsten and S. Hugh-Jones, eds, About the House: Levi-Strauss and beyond, pp. 84-104. Cambridge: Cambridge University Press. doi.org/10.1017/CBO97805116 07653.004 .

Janowski, Monica. 1998. 'Kelabit beads.' In Lidia D. Sciama and Joanne B. Eicher, eds, Beads and Bead Makers: Gender, material culture and meaning, pp. 213-46. Oxford: Berg.

Janowski, Monica. 2003a. The Forest: Source of life. The Kelabit of Sarawak. London and Kuching: British Museum and Sarawak Museum.

Janowski, Monica. 2003b. 'Masculinity, potency and pig fat: The Kelabit of Sarawak.' In Harlan Walker, ed., The Fat of the Land, pp. 130-42. London: Footwork.

Janowski, Monica. 2007a. 'Being "big”, being “good”: Feeding, kinship, potency and status among the Kelabit of Sarawak.' In Monica Janowski and Fiona Kerlogue, eds, Kinship and Food in Southeast Asia, pp. 93-120. Copenhagen: NIAS Press.

Janowski, Monica. 2007b. 'Feeding the right food: The flow of life and the construction of kinship in Southeast Asia.' In Monica Janowski and Fiona Kerlogue, eds, Kinship and Food in Southeast Asia, pp. 1-23. Copenhagen: NIAS Press.

Janowski, Monica. 2012. 'Imagining the forces of life and the cosmos in the Kelabit highlands, Sarawak.' In Tim Ingold and Monica Janowski, eds, Imagining Landscapes: Past, present and future, pp. 143-64. London: Ashgate. doi.org/10.4324/9781315587899-8.

Janowski, Monica. 2014a. 'Pigs and people in the Kelabit Highlands, Sarawak.' Indonesia and the Malay World 42(122): 88-112. doi.org/10.1080/13639811. 2013.869383. 
Janowski, Monica. 2014b. 'Puntumid: Great spirit of the heart of Borneo.' Indonesia and the Malay World 42(122): 120-22. doi.org/10.1080/136398 11.2014.869381.

Janowski, Monica. 2014/16. Tuked Rini, Cosmic Traveller: Life and legend in the heart of Borneo. Copenhagen and Kuching: NIAS Press and Sarawak Museum. [Published in paperback in 2014 and in hardback in 2016.]

Janowski, Monica. 2016. 'The dynamics of the cosmic conversation: Beliefs about spirits among the Kelabit and Penan of the upper Baram River, Sarawak.' In Kaj Århem and Guido Sprenger, eds, Animism in South East Asia, pp. 181204. London: Routledge. doi.org/10.4324/9781315660288-9.

Janowski, Monica. 2020. 'Stones alive! An exploration of the relationship between humans and stone in SE Asia.' Bijdragen tot de Taal-, Land-en Volkenkunde 176(1): 105-46. doi.org/10.1163/22134379-bja10001.

Janowski, Monica. 2019. 'Protective power: The nabau or water dragon among the Iban of Sarawak.' Sarawak Museum Journal LXXXI(81)(NS).

Janowski, Monica and Fiona Kerlogue, eds. 2007. Food and Kinship in Southeast Asia. Copenhagen: NIAS Press.

Janowski, Monica and Jayl Langub. 2011. 'Footprints and marks in the forest: The Penan and the Kelabit of Borneo.' In Graeme Barker and Monica Janowski, eds, Why Cultivate? Anthropological and archaeological approaches to foraging-farming transitions in Southeast Asia, pp. 121-32. Cambridge: McDonald Institute, University of Cambridge.

Kedit, V. 2009. 'Restoring Panggau Libau: A reassessment of engkeramba' in Saribas ritual textiles.' Borneo Research Bulletin 40: 221-48.

Kirsch, Thomas A. 1973. Feasting and social oscillation: A working paper on religion and society in upland Southeast Asia. Southeast Asia Program Data Paper No. 52. Ithaca, NY: Cornell University.

Kruyt, A.C. 1906. Het animisme van den Indische archipel [Animism in the Indonesian Archipelago]. 's-Gravenhage: Nijhoff.

Laderman, Carol. 1991. Taming the Wind of Desire: Psychology, medicine and aesthetics in Malay shamanistic performance. Berkeley, CA: University of California Press. doi.org/10.1525/california/9780520069169.001.0001.

Lian-Saging, R. 1976-77. 'An ethno-history of the Kelabit tribe of Sarawak: A brief look at the Kelabit tribe before World War II and after.' Graduation exercise, BA Hons, Jabatan Sejarah, University of Malaya, Kuala Lumpur. 
Lloyd-Smith, L., G. Barker, H. Barton, E. Boutsikas, D. Britton, I. Datan and B. Upex. 2013. 'The Cultured Rainforest project: Preliminary archaeological results from the first two field seasons (2007, 2008).' In Marijke J. Klokke and Veronique Degroot, eds, Unearthing Southeast Asia's Past: Selected papers from the International Conference of European Association of Southeast Asian Archaeologists. Volume 1, pp. 34-51. Singapore: National University of Singapore Press. doi.org/10.2307/j.ctv1qv3nd.9.

Lloyd-Smith, L., G. Barker, H. Barton, I. Datan, C. Gosden, B. Nyiri and E. Preston. 2010. 'The Cultured Rainforest project: Archaeological investigations in the third (2009) season of fieldwork in the Kelabit highlands of Sarawak.' Sarawak Museum Journal LXVII(88)(NS): 57-104.

McKinley, Robert. 1976. 'Human and proud of it! A structural treatment of headhunting rites and the social definition of enemies.' In George N. Appell, ed., Borneo Societies: Social process and anthropological explanation. Center for Southeast Asian Studies Special Report No.9. DeKalb, IL: Northern Illinois University.

McWilliam, Andrew. 1996. 'Severed heads that germinate the state: History, politics, and headhunting in southwest Timor.' In Janet Hoskins, ed., Headhunting and the Social Imagination in Southeast Asia, pp. 127-66. Stanford, CA: Stanford University Press.

Maxwell, A.R. 1996. 'Headhunting and the consolidation of political power in the early Brunei state.' In Janet Hoskins, ed., Headhunting and the Social Imagination in Southeast Asia. Stanford, CA: Stanford University Press.

Metcalf, Peter. 1982. A Borneo Journey into Death: Berawan eschatology from its rituals. Philadelphia, PA: University of Pennsylvania Press. doi.org/10.9783/ 9781512818079 .

Mills, J.P. 1926. The Ao Nagas. London: Macmillan \& Co.

Mills, J.P. 1935. 'The Naga headhunters of Assam.' Journal of the Royal Central Asian Society 22(3): 418-28. doi.org/10.1080/03068373508725375.

Needham, Rodney. 1976. 'Skulls and causality.' Man 11: 71-88. doi.org/ $10.2307 / 2800389$.

Rethinasamy, Souba, Norazila Abd. Aziz, Fitri Suraya Mohamad, Mohd Hafizan Hashim and Dayang Sariah Abang Suhai. 2013. 'Developing literacy and knowledge preservation skills among remote rural children.' In Ambigapathy Pandian, Christine Liew Ching Ling, Debbita Tan Ai Lin, Jayagowri Muniandy, Lee Bee Choo and Toh Chwee Hiang, eds, New Literacies: Reconstructing education and language, pp. 94-107. Cambridge: Cambridge Scholars Publishing. 
Rubenstein, Carol. 1973. 'Poems of indigenous peoples of Sarawak: Some of the songs and chants. Part II.' Sarawak Museum Journal XXI(12): 723-1127.

Sellato, B. 1983. 'Le Mythe du Tigre au Centre de Borneo [The myth of the tiger in central Borneo].' ASEMI 14(1-2): 25-49.

Skeat, Walter William and Charles Otto Blagden. 1900. Malay Magic: Being an introduction to the folklore and popular religion of the Malay Peninsula. London: Macmillan.

Tangherlini, Timothy R. 1990. "'It happened not too far from here”: A survey of legend, theory and characterization.' Western Folklore 49(4): 371-90. doi.org/ $10.2307 / 1499751$.

Uchibori, Motomitsu. 1978. 'The leaving of this transient world: A study of Iban eschatology and mortuary practices.' $\mathrm{PhD}$ thesis, The Australian National University, Canberra. Available from: hdl.handle.net/1885/111352.

Walker, John H. 2002. Power and Prowess: The origins of Brooke kingship in Sarawak. Sydney and Honolulu: Allen \& Unwin and University of Hawai i Press.

Wessing, R. 1986. The Soul of Ambiguity: The tiger in Southeast Asia. Center for Southeast Asian Studies Monograph Series on Southeast Asia Special Report No.24. DeKalb, IL: Northern Illinois University.

Winstedt, Richard. 1956. The Malays: A cultural history. London: Macmillan. 
This text is taken from Austronesian Paths and Journeys, edited by James J. Fox, published 2021 by ANU Press, The Australian National University, Canberra, Australia.

doi.org/10.22459/APJ.2021.05 